Buffalo Diseases and Research Department

Animal Health Research Institute, Dokki, Giza

\title{
RAPID DETECTION OF ENTEROTOXIGENIC $E$. COLI RECOVERED FROM BUFFALO MEAT PRODUCTS USING PCR.
}

(With 3 Tables)

By

E.R. ZAKI and A.M. EL-MAHROUK*

*Microbial Toxins Research Unit

Animal Health Research Institute, Dokki, Giza

(Received at 6/11/2004)

\section{الكشف السريع للايشريشية القولونية المعوية السامة المعزولة من منتجات

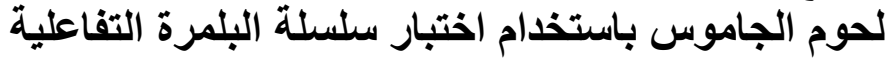 عماد رزق الله زكى ، عاطف محد عمر}

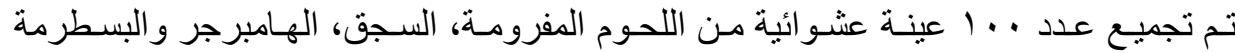

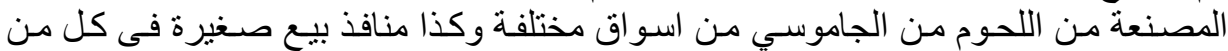

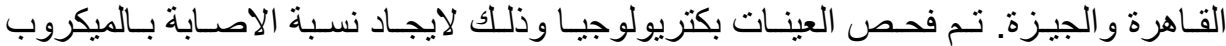

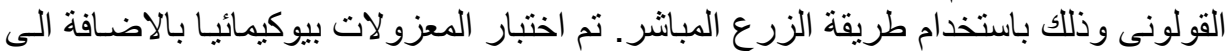

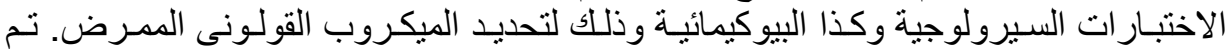

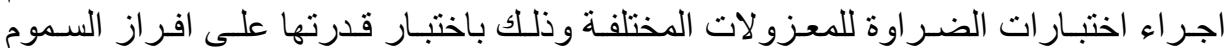

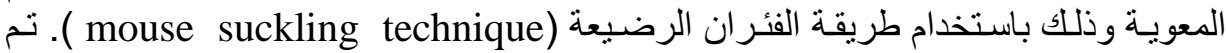

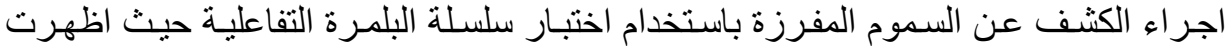

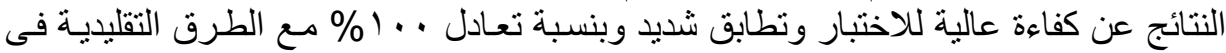
التشخيص وكذا الكثف عن السموم.

\section{SUMMARY}

A total of 100 random samples each from meat products from buffalo meat (fresh minced meat, sausage, beef burger and basterma) were collected from different markets and small shops in Cairo city, Egypt. All samples were examined bacteriologically to determine the prevalence of $E$. coli using direct plate technique. Recovered isolates were subjected for biochemical identification, biotyping as well as serolological characterization for detection of enteropathogenic E. coli serovars. All isolates were tested for their virulence by examining their 
ability to produce E.coli heat stable enterotoxins using mouse suckling technique and Polymerase Chain Reaction to detect gene encoding for the heat stable enterotoxins STI.

Key words: E.coli, PCR, buffalo meat, meat products.

\section{INTRODUCTION}

The pathogenic strains of Escherichia coli recovered from the intestinal tract of animals fall into four categories called enterotoxigenic, enteropathogenic, enterohemorrhagic and necrotoxigenic. The other two categories, are enteroinvasive and enteroaggregative (DebRoy and Maddox, 2001).

There is still only a very limited amount of information on the efficacies of the various protocols in detecting bacterial pathogens especially toxigenic Escherichia coli in naturally contaminated food samples. In order to develop toxic gene amplification protocols that have relevance to the meat industry there must be a concerted effort to utilize naturally contaminated samples in the development and evaluation of protocols as well as to initiate multilaboratory about robin evaluations of select protocols. Availability of multilaboratory tested methodologies would provide a means to design pathogen detection strategies at the quality control level rather than an end product confirmatory response to an already documented outbreak (MacDonald et al., 2004).

Food may be derived from a source free from microbial contaminants but becomes contaminated in the course of manufacture transport or sale to food handlers, utensils, air, soil and incomplete hygienic conditions during manufacturing like packaging, storage, slicing and marketing of such products promote the growth and multiplication of various bacteria one of which being Escherichia coli (Bryan, 1982).

The native habitat for Escherichia coli is the intestinal tract of man and animals; therefore its presence in food generally indicates direct or indirect pollution of faecal origin. Escherichia coli is the classical indicator of the possible presence of enteric pathogens in food. On the other hand, meat products constitute a public health hazard either due to the presence of spoilage bacteria responsible for unfavorable changes or pathogenic bacteria like Escherichia coli which can lead to harmful effects as infection or intoxication in consumers (Mehlman and Romero, 1982). 
Polymerase chain reaction is an in-vitro amplification technique for enzymatic synthesis of specific DNA sequences using two oligonucleotide primers that hybridize to opposite strands and flank the region of interest in the target DNA. A repetitive series of cycles involves: template denaturation, primer annealing, and extension of the annealed primers by thermostable DNA polymerase (Erlich et al., 1991). PCR is used now in large scale as a recent techniques for detection of virulence factors in enterotoxigenic Escherichia coli serotypes in meat and meat by products (Feng and Monday, 2000 and Makino et al.,2000). Enterotoxigenic E.coli strains have been known to cause traveler's diarrhea, gastrointestinal infection and diarrhoeal illness (Sharp et al.; 1995). Such strains are known to produce heat-labile enterotoxins (LT) that are antigenic and similar to cholera enterotoxin and/or a heat-stable enterotoxin (ST) that are of small molecular weight and are nonantigenic (Frank et al., 1977 and Niazi and Refai 1988).

Public health authorities began to reevaluate the role of Escherichia coli in food and water illness, the routine laboratory screening for Escherichia coli in food is now not restricted only for the isolation, biochemical and serological identification of enteropathogenic Escherichia coli (EPEC) incriminated in food outbreaks, but it is extended to detect enterotoxigenic Escherichia coli (ETEC) (Niazi and Refai, 1988).

The present work was planed to illustrate the significance of the presence of E.coli in meat products through the following:

1-Incidence of Escherichia coli in meat products (raw minced meat, fresh sausage, frozen beef burger and basterma slices).

2-Detection of enterotoxigenic strains of $E$.coli by mouse suckling test.

3-STI gene detection for identification of enterotoxigenic isolates of $E$. coli by PCR using STI specific primers.

\section{MATERIALS and METHODS}

A total of 100 random samples each from fresh minced meat, sausage, beef burger and basterma were collected from different markets and small shops in Cairo, Egypt.

All samples were prepared according to the technique recommended by ICMSF (1978) as follows:

Twenty five grams of each meat sample were transferred to a sterile blender jar to which $225 \mathrm{ml}$ of sterile $0.1 \%$ peptone water was added to provide a solution of meat to peptone water $1 / 10$. The blander 
was operated at $2000 \mathrm{rpm}$. for 2.5 minutes. The homogenate was then allowed to stand for 15 minutes at room temperature. The content of the jar was mixed by shaking before applying the following:

\section{1- Direct plate technique (DPC)}

Surface spread plate method recommended by Barraud et al. (1967) was followed. From each plate, glistening circumscribed completely separate colonies were selected and subcultured on smaller plates containing the same medium and kept as stock culture. Isolates were subjected for Gram's stain (Colle et al., 1996) and were biochemically identified according to Bailey and Scott (1990) .

\section{Serological identification of enterotoxigenic $E$. coli:}

Agglutination test was carried out according to Edwards and Ewing (1972). Each isolate was first tested for its agglutinability to the diagnostic OK polyvalent sera (Welcome) which were intended for use by slide agglutination technique. Once the pathogenic type has been indicated by the use of polyvalent sera, further serotyping was made with the appropriate OK monovalent sera.

Biotyping of the isolates:

Biotyping was determined according to Burrow (1985) by using of carbohydrates fermentation, decarboxylation of lysine and ornithine, and hydrolysis of esculin tests.

\section{Identification of enterotoxigenic Escherichia coli (ETEC) isolates:}

All isolates of $E$. coli were tested for their ability to produce heat stable (ST) enterotoxin by applying mouse suckling technique as well as PCR techniques .

\section{Samples preparation for recovery of enterotoxin:}

The isolated $E$. coli strains were grown over night in brain heart infusion broth and then inoculated in culture medium $(10 \mathrm{ml}$ of casamino acids yeast extract medium) in a $250 \mathrm{ml}$ Erlenmeyer flask prepared specifically for production of toxins according to Evans et al. (1973). After inoculation, the flasks were incubated with shaking on rotatory shaker at $37^{\circ} \mathrm{C}$ for 24 hours. The culture fluid was centrifuged at $250 \mathrm{x} \mathrm{g}$ for $30 \mathrm{~min}$. at $4^{\circ} \mathrm{C}$. The supernatant was then taken and subjected to heat treatement $\left(80^{\circ} \mathrm{C}\right.$ for $30 \mathrm{~min}$. ) before storing at $-70^{\circ} \mathrm{C}$ for detection of heat stable enterotoxin (ST) .

\section{Detection of heat stable enterotoxins (ST) among $E$. coli isolates.}

It was carried out using suckling mouse test according to the method of Giannella (1976). 


\section{PCR techniques for detection of enterotoxigenic $E$. coli enterotoxins (STI) gene.}

$E$.coli plasmid DNA was isolated by the alkaline lysis method (Birnboim and Dolly 1979). Briefly single colonies from individual isolates were inoculated in $4 \mathrm{ml} \mathrm{LB}$ (bacto-tryptone $10 \mathrm{~g}$. bacto yeast extract $5 \mathrm{~g}$. $\mathrm{NaCl} 10 \mathrm{~g}$.per $1 \mathrm{~L}_{2} \mathrm{O}$ ) medium and grown overnight at $37^{0} \mathrm{C}$ on a shaker. Next day the bacterial culture was transferred to a sterile Eppendorf tube and centrifuged for $15 \mathrm{sec}$. at $14000 \mathrm{rpm} / 4^{0} \mathrm{C}$. The supernatant was discarded and this procedure was repeated once. Then the bacterial pellet was resuspended in $200 \mu \mathrm{l} \mathrm{GTE}$ solution $(50 \mathrm{mM}$ Glucose,25mM Tris-HCL pH-8,0 10mM EDTA pH-8,0) by vortexing. Next $300 \mu 1$ cell lysis solution was added (freshly prepared $0,2 \mathrm{~N} \mathrm{NaOH}$, $1 \%$ sodium dodecyl sulfate). Tubes were gently inverted 5 times in order the two solutions to be mixed. Next $300 \mu 1$ neutralization solution $(5 \mathrm{M}$ Sodium Acetate) was added to the tubes and then tubes were centrifuged at $14000 \mathrm{rpm} / 4^{0} \mathrm{C}$ for $10 \mathrm{~min}$ in order bacterial proteins to be removed. Next to the supernatant $800 \mu 1$ 2-propanol was added tubes inverted and centrifuged at $14000 \mathrm{rpm} / 4^{0} \mathrm{C}$ for $10 \mathrm{~min}$ in order to precipitate plasmid DNA. The pellet was washed once with $70 \%$ Ethanol allowed to dry for $10 \mathrm{~min}$ at room temperature with tubes inverted and dissolved in $500 \mu \mathrm{l}$ autoclaved water. To this solution $10 \mu \mathrm{l}$ RNA-ase $\mathrm{H}(10 \mathrm{mg} / \mathrm{ml})$ was added and the tubes were incubated at $37^{\circ} \mathrm{C}$ for $30 \mathrm{~min}$. Next the plasmid DNA was extracted with $500 \mu$ l Phenol/Chlorophorm. Tubes were vortexed and centrifuged $10 \mathrm{~min} / 4^{\circ} \mathrm{C}$. and then the water phase was extracted only with Chlorphorm with the same centrifugation step. Finally the pure plasmid DNA was precipitated by adding to the supernatant $50 \mu \mathrm{l} 3 \mathrm{M}$ Sodium acetate and $500 \mu$ 2-propanol, centrifuged $14000 \mathrm{rpm} / 4^{0} \mathrm{C}$ for $20 \mathrm{~min}$., washed by $70 \%$ Ethanol, allowed to dry for $10 \mathrm{~min}$ at room temperature with tubes inverted and dissolved in $50 \mu \mathrm{l}$ autoclaved water. Five microliters from isolated plasmid DNAs was checked by $0.7 \%$ agarose gel electrophoretic analysis with $1 \mathrm{x}$ TAE buffer (0.04M Tris-acetate, 0,001M EDTA) as electrophoretic buffer, and stained with ethidium bromide, visualized under UV light and photographed. Plasmid DNA was stored at $-20^{\circ} \mathrm{C}$.

STI enterotoxins gene was detected by PCR using the set or primers and PCR conditions reported by Hau-YangTsen and Chi, (1996). PCR was done in total volume of $20 \mu 1$ in a thermal cycler.

To $500 \mu \mathrm{g}-1 \mu \mathrm{g}$ plasmid DNA

$2 \mu 1$ 10xPCR buffer,

$2 \mu 1$ DNTPs $(25 \mu 1 \mathrm{M}$ each) 
$1 \mu 1$ Each primer $(\rho \mathrm{M} 10)$

$0,5 \mathrm{U}$ Taq DNA polymerase

Water to $20 \mu 1$

STI-P1:5'GGAGGTAAIATGAAIAAIIIAATITT3'

STI-P2:5'TTACAACAIAITTCACAGCAGTAA3'

PCR conditions

Denaturation $94^{0} \mathrm{C} / 20 \mathrm{sec}$.

Annealing $50^{\circ} \mathrm{C} / 30 \mathrm{sec}$.

Extension $72^{0} \mathrm{C} / 30 \mathrm{sec}$.

Final extension $72^{0} \mathrm{C} / 2 \mathrm{~min}$.

Total number of cycles 40 .

After the amplification the PCR product was resolved on $2 \%$ agarose gel and visualized as described above.

\section{RESULTS and DISCUSSION}

Traditionally, microbiological testing of meat products has involved isolating microorganisms from meat samples and performing specific biochemical, and in some cases serological tests to confirm the presence or absence of suspected food-borne pathogens. Given the public attention meat products have received as sources of food-borne disease, there has been considerable interest in the application of rapid detection techniques that require hours rather than days for completion. Theoretically, rapid detection methods could reduce the time from the initial sampling to confirmation so that conclusive results would be available by the time to process the meat product (Pillai and Ricke, 1995).

In this study a total of 100 samples of minced meat, sausage, beef burger and basterma from buffaloes origin were used for investigation of the presence of enterotoxigenic strains of $E$. coli. The results showed that $E$. coli was isolated from minced meat with an incidence of $(44 \%)$ followed by $40 \%, 12 \%$ and $8 \%$ from sausage, beef burger and basterma respectively (Table 1 ) 
Table 1: Prevalence of $E$. coli in relation to its biovar.

\begin{tabular}{|c|c|c|c|c|c|}
\hline \multirow[t]{2}{*}{ Samples } & \multirow{2}{*}{$\begin{array}{l}\text { Total no. of } \\
\text { examined } \\
\text { samples }\end{array}$} & \multicolumn{2}{|c|}{$\begin{array}{l}\text { positive } \\
\text { samples }\end{array}$} & \multirow[t]{2}{*}{ Biovar I } & \multirow[t]{2}{*}{ Biovar II } \\
\hline & & No. & $\%$ & & \\
\hline Minced meat & 25 & 11 & 44 & 5 & 6 \\
\hline Sausage & 25 & 10 & 40 & 9 & 1 \\
\hline Beef burger & 25 & 3 & 12 & 2 & 1 \\
\hline Basterma & 25 & 2 & 8 & 1 & 1 \\
\hline
\end{tabular}

Biochemical characterization of E.coli isolated from meat and meat products is considered as an important primary routine examination of environmental food specimens (Mehlman and Romero 1982). E.coli biotype $\mathrm{I}$ is generally recommended as an indicator of direct or indirect faecal or non fecal contamination of food, particularly meat and meat products (Mossel, 1962). With good manufacturing practice, E.coli contamination on meat is generally considered to come from skin or hide of animals during processing (Newton et al., 1977). Furthermore, E.coli biotype I in the stationary growth phase survives well in frozen and fresh meat (Stiles and Lai-King 1981) and grow in meat at improper storage temperature.

The high frequency of E.coli biotype we recovered from tested meat products and identified biochemically, this finding is in agreement with previous reported by Anderson and Parker (1975) ; Stiles and LaiKing (1981) and Mehlman and Romero (1982) who recorded that E.coli biotype I was detected as the most common E.coli biotype at all stages of meat handling. This indicates that it may be present in meat throughout the meat handling system' (raw meat contact surface, beef work surface paking plants and equipments).

The presence of atypical E.coli (biovar II) particularly E. blattae and E.inactive in tested raw minced meat and fresh sausage is also indication of potential contamination as well as of public health significance. In this respect, Arbuzova (1970) and Melechenev (1970) reported that some enteropathogenic E.coli strains isolated from children and adults with diarhoea were belonging biochemically to atypical E.coli and/ or non lactose fermenters.

On the other hand, the two strains of atypical E.coli recovered from beef burger and basterma (one strain each) were identified as E.blattae. Furthermore, the present study has demonstrated that E.coli 
biovar I (or typical) was the principle biotype occurring in meat products with total frequency of $70 \%$.

Table 2: Serotyping of E. coli isolates in different samples

\begin{tabular}{|c|c|c|c|}
\hline \multirow{2}{*}{ Samples } & \multicolumn{3}{|c|}{ Serotypes } \\
\cline { 2 - 4 } & Serovar type & No. & $\%$ \\
\hline Minced meat & O44: K47 & 2 & 16.6 \\
& 0124: K72 & 1 & 8.3 \\
O127:K63 & 1 & 8.3 \\
Sausage & 0124: K72 & 1 & 8.3 \\
& O78:K80 & 1 & 8.3 \\
& O86:K61 & 1 & 8.3 \\
& O111:K58 & 1 & 8.3 \\
Beef burger & O124:K72 & 1 & 8.3 \\
& O25:K11 & 2 & 8.3 \\
Basterma & Untypable & 12 & 16.6 \\
\hline Total & &
\end{tabular}

Serotypes of all isolates were determined and the results obtained showed that all isolates from meat products samples could be identified by certain OK serotypes except for basterma which showed that all isolates were non typable and this may be attributed to the less number of serotypes according to the company used (Table 2).

Out of 26 E.coli isolates recovered from different meat product samples tested, only 12 isolates (46\%) could be serologically typed as enteropathogenic E.coli (EPEC). These strains revealed 7 different classic EPEC serovars namely O124:K72 (B17) and 044: K74 (2 strains) and one strain from each of O86:K61, O25:K11, O78:K80, O111:K58 and $\mathrm{O} 127: \mathrm{K} 63$.

The serovar 0124: K72 was recovered from fresh minced meat (1 strains.), fresh sausage (1 strains) and beef burger (one strain). The serovars O44:K74 (2 strains) and 0127 :K63 (one strain) were isolated only from raw minced meat, whereas the serovars O78: K80, O86: K61 and 0111:K58 were recovered from fresh raw sausage and the serovar $\mathrm{O} 25: \mathrm{K} 11$ was obtained only from the frozen beef burger.

None of E.coli strains recovered from basterma slices were enteropathogenic. These findings are nearly similar to those recorded by Gobran (1985), Niazi and Refai (1988) for E.coli serotypes isolated from raw minced meat, fresh sausage and beef burger. 
In this respect, Gobran (1985) isolated E.coli serotype O86: K61, 0111: K58, 0125: K70, 0127:K63 and 0114:K90 from manufactured minced meat and only the serotype O55: K59 from sausage. Moreover Niazi and Refai (1988) identified serologically the E.coli serovars recovered from minced meat and sausage as 026:K61, 055: K59, O86: K61, 0111: K58, O114:K 9o, K119 :K 69, 0124: K72 and O128:K 67.

Furthermore the findings that enteropathogenic E.coli was failed to be detected in basterma samples as previously reported by Saad (1976) and Gobran (1985) confirmed what have been reported in the present study that the isolated E.coli from basterma were untypable strains.

Most of the detectable classic enteropathogenic E.coli (EPEC) isolated from the tested meat products samples particularly minced meat, sausage and beef burger were previously reported to be incriminated in different infantile diarrhoea and gastrointestinal outbreaks in adult human (Klipstein et al., 1978 and Edelman and Levine, 1983).

Out of the E. coli strains obtained from meat products samples, 5 isolates $(19.3 \%)$ were found to be enterotoxigenic E.coli (ETEC) (Table 3). Only four E.coli strains were belonging to the classic EPEC (Serovars O25:K11, 044:K74, O86:K61 and O111: K58) were found to be enterotoxigenic E.coli (ETEC) including two strains of serotype O44:K74 recovered from minced meat produced one E.coli serotype $\mathrm{O} 25: \mathrm{K} 11$ recovered from beef burger produced ST, one strain belonging to serovar O86:K61 recovered from fresh sausage and one isolate of $E$. coli serotype O111: K58 recovered from fresh sausage. Meanwhile none of other classic enteropathogenic serovar could produce enterotoxin.

Table 3: Correlation between E. coli serovars and nterotoxigenic E. coli

\begin{tabular}{|c|c|c|c|}
\hline \multirow{2}{*}{ Samples } & \multicolumn{3}{c|}{ E. coli isolates } \\
\cline { 2 - 4 } Minced meat & Serovar type & No. & Toxins producer \\
& O44: K74 & 2 & Stable toxin \\
& 0124: K72 & 1 & Non \\
O127:K63 & 1 & Non \\
Sausage & 0124: K72 & 1 & Non \\
& O78:K80 & 1 & Non \\
& O86:K61 & 1 & Stable toxin \\
& O111:K58 & 1 & Stable toxin \\
Beef burger & O124:K72 & 1 & Non \\
& O25:K11 & 1 & Stable toxin \\
\hline
\end{tabular}




\section{Basterma}

Untypable

2

Non

Some of outbreaks of diarrhoea in which certain E.coli strains belonged to the EPEC group have been incriminated due to LT and/or ST producing strains, while others have been due to EPEC strain with other virulence factors Niazi and Refai (1988). In this respect, Addy et al. (2004) and Muza et al. (2004) reported that enteropathogenicity at least of classic EPEC strains which do not produce LT or ST, is due to another enterotoxins which is not detected by standard test for ST and LT e.g. cytotoxin, verotoxin or VT which differ from LT and ST (Scotland et al., 1981). Moreover, Orskov et al. (1977) recorded that the enterotoxigenic strains (ETEC) generally belonged to serovars different from those of enteropathogenic E.coli strains. Klipstein et al. (1978) pointed out that the property of enterotoxigenicity is clearly not restricted to enteropathogenic serotypes, Both enteropathogenic and nonenteropathogenic serotypes have been shown to be toxigenic as measured by biological and serological tests and appears to be isolated from persons with acute diarrhoea. The classic antigenic determinants of enteropathogenic serotypes are chromosomally mediated, whereas both enterotoxin production and the presence of surface antigens which promote adhesion to mucosal surface are plasmid encoded, (Gyles and Falkow., 1974 and Evans et al., 1975).

In comparing the incidence of enterotoxigenic E.coli among the total isolates of E.coli recovered from food, Sack et al., (1977) found that $8 \%$ of 248 isolates obtained from food of animal origin were enterotoxigenic. Serafim et al., (1979) stated that $10 \%$ of E.coli recovered from sausage and hamburger were enterotoxigenic while Niazi and Refai (1988) recorded that $21.87 \%$ of E.coli strains recovered from raw minced meat and raw sausage belonged to the enterotoxigenic type (ETEC).

Some of the classic EPEC serovars found in the present study O25:K11, O44:K80, O86:K61 and O111:K58 were identified also here as enterotoxigenic types which are very common cause of infantile diarrhoea and travellers diarrhoea (Wood et al., 1983 and Kristine et al., 1985).

Regarding the incidence of E.coli implication in cases of gastroenteritis and or infants diarrhoea in Egypt, it was estimated by different authors as follows 18\% (Abd Eil-Aziz , 1987),-13.58\% (Ahmed, 1980), 16\% (Ibrahim, 1981) and 54\% (Marzouk,1985). On the other hand, Matsievskii et al. (1971) recorded that the serotype O124: 
K72 of E.coli isolated from a total of 198 children and 90 personnel members of children's sanatorium was implicated in acute outbreak of food poisoning among them. The E.coli serotype 0124:K72, was recovered from raw minced meat and raw sausage tested in the present investigation.

Many researchers recommended the modern molecular biology techniques as diagnostic tools ,they concluded that in comparison to culture method, PCR was found to be more sensitive method and yielded the highest percentage of positive results. In addition PCR techniques fasten the diagnosis and minimize labor needed for isolation (Pinnow et al., 2001).

So, it become convenient and also needed for a technique to be applicable for detection of enterotoxigenic isolates and PCR is one of the promising techniques, Results obtained here were in concurrence by using mouse sucking techniques as all the four isolates detected were also positive by PCR techniques with an incidence of $100 \%$.

$\begin{array}{lllllllll}\text { bp } & 1 & 3 & 5 & 7 & 9 & 11 & 13 & 15\end{array}$

0

40

0

20

Detection of heat stable toxins 1(ST1) gene in E. coli plasmid DNA using PCR primer pairs ST1-P 1/ST1-P2 


\section{REFERENCES}

Abd Eil-Aziz, A.A. (1987): Microbial load of some meat products as influenced by hygienic status of the producing plant. M.Sc., Thesis, Cairo University.

Addy, P.A.; Antepim, G. and Frimpong E.H. (2004): Prevalence of pathogenic Escherichia coli and parasites in infants with diarrhoea in Kumasi, Ghana. East Afr. Med. J.; 81(7): 353-7.

Ahmed, A. (1980): Studies on acute gastrointestinal infection in Assiut Governorate. Univ.

Anderson -Judith M. and Baird Parker, A.C. (1975): A rapid and direct plate method for enumerating Escherichia coli biotype 1 in food. J. Appl. Bact. 39, 111-117.

Arbuzova, V.A. (1970) : Nosocomial gastroenteritis, Arizona Morbidity Mortality 22, 225.

Bailey, W.R. and Scott E.G. (1990): Diagnostic Microbiology, $7^{\text {th }}$ ed C.V.Mosby co., U.S.A.

Barraud, C.; Kitchell, H.G.; labots, H.; Rentev, G. and Simonsen, B. (1967): Standardization of the total aerobic count in meat and products. Fleischwirtschaft, 47, 1313.

Birnboim, H.C. and Doly, J. (1979): A rapid alkaline extraction procedure for screening recombinant plasmid DNA. Nucleic Acids Res. 71513

Bryan, F.L. (1982): Diseases transmitted by foods. $2^{\text {nd }}$ HHS Pub. No. (CDC) 83-8327, US Spet. Of Health and Human Service , Center for diseases control, Atlants, Gorgia 30, 333 USA.

Burrows, (1985): Textbook of Microbiology 22nd Edition. The C.V. Mosby Company.

Collee, J.G.; Marmion, B.P.; Fraser, A.G. and Simmons, A. (1996): Mack and MacCartney practical medical microbiology, 4th ed. Churchill Livingstone, N. Y. London.

DebRoy, C. Maddox, C.W. DebRoy and Maddox (2001): Identification of virulence attributes of gastrointestinal Escherichia coli isolates of veterinary significance. Anim Health Res. Rev.; 2(2): 129-40.

Edelman, R. and Levine, M.M. (1983): Summary of a workshop on enteropathogenic Escherichia coli. J. Infect. Dis. 147, 11081118. 
Edwards, P.R. and Ewing N.H. (1972): Identification of Enterobacteriaceae 3rd Ed.Burgman publishing, Co.; Atlanta, U.S.A., 208-239.

Erlich, H.A.; Gelfand, D. and Sninsky, J.J. (1991): Recent advances in the polymerase chain reaction .Science, 252:1643 -1651

Evans, D.J., Evans, D.G. and Strabach, S.L. (1973): Production of vascular permeability factor by enterotoxigenic Escherichia coli isolated from man. Infect. Immunol.,8, 725-730.

Evans, D.G.; Silver, R.P., Evans, D.J., chase, Jr.D.G. and Gorbach, S.L. (1975): Plasmid controlled colonization factor associated with virulence in Escherichia coli enterotoxigenic for humans. Infect. Immmune. 12: 656-667.

Feng P, Monday S.R. (2000): Multiplex PCR for detection of trait and virulence factors in enterohemorrhagic Escherichia coli serotypes. Mol Cell Probes. 14(6): 333-7.

Frank, J.F.; Hartin, E.H. and Olson, N.F. (1977): Survival of enteropathogenic and non pathogenic Escherichia coli during the manufactured of camembert cheese. J. Food Protect 40, 835-841.

Giannella, R.A. (1976): Suckling mouse model for detection of heat stable Escherichia coli enterotoxin characteristics of the model. Infect. Immunol., 14, 95-99.

Gobran, R.A. (1985): Enterobacteriaceae in meat products in Upper Egypt. M.V.Sc. Thesis, Assiut University.

Gyles, C. So. M. and Folkow, S. (1974): The enterotoxin plasmid of Escherichia coli. Journal Infections Diseases 130, 40.

Hau-YangTsen and Wan-Rong Chi (1996): Plasmid profile analysis for Enterotoxigenic Escherichia coli and detection of heat stable enterotoxin 1 (ST1) gene by polymerase chain reaction. Journal of Food and Drug Analysis. 4,3.

Ibrahim, A.M. (1981): Sanitary condition of locally produced Hamburger, M.V.Sc. Thesis, Cairo University.

ICMSF (1978): International Commission on Microbiological specification for Food. Microorganisms in Foods, their Significance and Methods of Enumeration, Vol. $12^{\text {th }}$ Ed. Univ. of Toronto Press, Toronto Buffaloes Canada.

Klipstein Frederick A.; Rowe Bernard; Engert Ritchard, F.; Shorty Helen, B. and Gross Roger, J. (1978): Enterotoxigenicity of Enteropathogenic serotypes of Escherichia coli isolated from 
infants with epidemic diarrhoea. Infection and Immunity, July, $\mathrm{P}$ 171-178.

Kristine, L.M.; Eidson, M.; Strohmeyer, C.; Levy, H.E.; Wells, J.G.; Puhr, N.D.; Wachsmuth, K.; Hargrelt, N.T. and Cohen, M.L. (1985): A multistate outbreak of gastrointestintal illness caused by enterotoxigenic Escherichia in imported semisoft cheese. J. Infect. Dis., 151 (4),- 716-720.

MacDonald DM, Fyfe M, Paccagnella A, Trinidad A, Louie K, Patrick D.MacDonald (2004): Escherichia coli O157:H7 outbreak linked to salami, British Columbia, Canada, 1999 Epidemiol Infect. 2004 Apr; 132(2): 283-9. Marier (1973)

Makino S.; Kobori, H.; Asakura, H.; Watarai, M.; Shirahata, T.; Ikeda, T.; Takeshi, K. and Tsukamoto, T. (2000): Detection and characterization of Shiga toxin-producing Escherichia coli from seagulls. Epidemiol Infect. 125(1): 55-61.

Marzouk, I. (1985): A study on microbial etiology of infantile diarrhoea, serumelectrolyte changes and agent related efficiency of antisecretory drug (Chlorpromexine). M.M.D., Pediatrics, Fac. Med., Alex. Univ.

Matsievskii, V.; Logachev, A. Fedorina, A. and Risklova, A. (1971): Outbreak of food poisoning caused by E.coli 0124:K72 (B17). Zhurnal Mikrobiologu, Epidemiologw. Immunobiology 48, 137. Dairy Sci. Abst., 35, 388.

Mehlman, J.J. and Romero, A. (1982): Enteropathogenic E.coli, Methods for recovery from foods. Food Tech., 36,3, 73.

Melechenev, L.F. (1970): Clinical /epidemiology characteristics of illness caused by Escherichia coli .Voenno Meditskii Zh. 7, 54.

Mossel, D.A.A. (1962): An ecological investigation on the usefulness of Eijkmon`s test as one of the methods used for the detection of faecal contamination of foods. J. Appl. Bacteriol. 25: 20-29.

Muza-Moons M.M.; Schneeberger, E.E. and Hecht, G.A. (2004):

Enteropathogenic Escherichia coli infection leads to appearance of aberrant tight junctions strands in the lateral membrane of intestinal epithelial cells.Cell Microbiol.; 6(8): 783-93.

Newton, K.G.; Harrison, J.C.L. and Smith, K.M. (1977): Coliforms from hides and meat. Appl. Envion. Microbiol., 33 (1), 199-200.

Niazi, Z.M. and Refai, M. (1988): Isolation of enteropathogenic and enterotoxigenic Escherichia coli from meat and cheese.Vet. Med. J. 36 (1), 127-134. 
Orskov, I. and Orskov, S. (1977): Special O: K: H serotypes among Enterotoxigenic Escherichia. coli strains from adults and children. Med. Microbiol. Immunol., 163: 99 - 110.

Pillai, S.D. and Ricke S.C. (1995): Strategies to accelerate the applicability of gene amplification protocols for pathogen detection in meat and meat products. Crit Rev Microbiol. ;21(4):239-61.

Pinnow, C.C.; Butler, J.A.; Sachse, K.; Hotzel, H.; Timms, L.L. and Rosenbusch, R.F. (2001): Detection of Mycoplasma bovis in preservative treated field milk samples. Journal of Dairy Science. 84 (7): 1640-1645.

Saad, S.M. (1976): The sanitary condition of locally manufactured basterma. M.V.Sc. Theis (Food Hygiene), Faculty of Vet.Med. Zagazig Univ.

Sack, D.A.; Mclaughlin, J.C.; Sack, R.B.; Orskov, P. and Orskov, I. (1977): Enterotoxigenic Escherichia coli isolated from patients at a hospital in Dacca. J. Infect. Dis 135:275-280.

Scotland, S.M.; Day, H.P.; Cravioto, A.; Thoman, L.V. and Rowe, B. (1981): Production of heat labile or heat stable enterotoxin by strains of Escherichia coli belonging to serogroups of 044, 0114 and 0128. Infect and Immunity 31, 500-503.

Serafim, M.B.; Pestama de Castro, A.F.; Lemos dos Ries and Trabuisi, L.R. (1979): Passive immune hemolysis for detection of heatlabile enterotoxin produced by Escherichia coli isolated from different sources. Infection and Immunity , 1979,24,(3),606610.

Stiles, M.E. and Lai-King, N.G. (1981): Biochemical characteristics and identification of Enterobacteriaceae isolated from meats. Appl and Environ Microbiol, : 639-645.

Wood Linsey, V.; Ferguson, L.E.; Hogan, P.; Thurman, D.; Morgan, D.R.; Dupont, H.L. and Ericsson, C.D. (1983): Incidence of bacterial enteropathogenic in food from Mexico. Appl. and Environ Microb.46.328-332. 
Assiut Vet. Med. J. Vol. 51 No. 104 January 2005 